\title{
Activation of proacrosin by a locally produced component of human follicular fluid
}

\author{
J. Drahorád, D. Čechová and J. Tesařík* \\ Institute of Molecular Genetics, Czechoslovak Academy of Sciences, Flemingovo nám, 2, Praha 6, \\ 166 37, Czechoslovakia, and *First Department of Obstetrics and Gynaecology, Faculty of \\ Medicine, J. E. Purkyně University, Brno, 600 00, Czechoslovakia
}

\begin{abstract}
Summary. Components of human follicular fluid were separated on Sepharose 6B columns and the effects of different fractions on the conversion of pig proacrosin to acrosin were examined. A high-molecular-weight fraction $\left(M_{\mathrm{r}}>3000000\right)$ of follicular fluid was a potent stimulator of this reaction. The proacrosin converting activity was absent in the corresponding fraction of blood serum. The acceleration of proacrosin activation was dependent on the concentration of material with proacrosin converting activity. The results indicate that human follicular fluid contains a highmolecular-weight component of local origin which is capable of accelerating proacrosin in a dose-dependent manner.
\end{abstract}

Keywords: proacrosin; acrosin; zymogen activation; follicular fluid

\section{Introduction}

Modulation of activities of enzymes essential for fertilization is supposed to be one factor of the complex of events leading to sperm fertilizing ability in the period preceding sperm-egg interaction. Acrosin (EC 3.4.21.10), a trypsin like serine proteinase, is present in the acrosome of ejaculated mammalian spermatozoa in the zymogen form, proacrosin (Polakoski \& Parrish, 1977; Tobias \& Schumacher, 1977; Harrison \& Brown, 1979). The conversion of the zymogen to the active form of the enzyme takes place some time before fertilization, during the acrosome reaction (Green, 1978). This process may occur spontaneously, by autoactivation triggered by the disruption of the acrosome (Brown \& Harrison, 1978). Alternatively, proacrosin activation may be accelerated significantly by various activators among which glycosaminoglycans seem to be of prime importance (Parrish et al., 1980). These compounds also enhance the incidence of the acrosome reaction in vitro in bovine (Handrow et al., 1982; Lenz et al., 1983a), rabbit (Lenz et al., 1983b), pig (Reyes et al., 1984) and hamster (Meizel \& Turner, 1986) spermatozoa. Research has focussed on the presence of such activators in the fluids of the female genital tract. Indeed, glycosaminoglycans of pig uterine fluid (Wincek et al., 1979) and of rhesus monkey oviduct fluid (Stambaugh \& Mastroianni, 1980) have been shown to stimulate proacrosin activation. To the best of our knowledge, follicular fluid of any mammalian species has not yet been tested for its possible proacrosin converting activity, although its stimulating effect on the sperm acrosome reaction is well known (e.g. Mukherjee \& Lippes, 1972; Oliphant et al., 1977; Tesarík, 1985). In this study we investigated the effects of different Sepharose 6B column fractions of human follicular fluid on activation of pig and human proacrosin. The results were compared with those using corresponding fractions of human blood serum instead of follicular fluid.

\section{Materials and Methods}

Source and preparation of proacrosin. Pig semen was obtained from healthy mature boars (Large White). After the seminal plasma had been removed by centrifugation of the semen at $1000 \mathrm{~g}$, for $10 \mathrm{~min}$, the spermatozoa were 
resuspended in 5 mM-MES (Serva Feinbiochemica, Heidelberg, West Germany), pH 6.5, containing 0.264 m-sucrose (Brown \& Harrison, 1978) and centrifuged as above; the procedure was repeated twice.

Human ejaculates, obtained from healthy husbands of patients treated by in-vitro fertilization and embryo transfer, were left to stand for $30 \mathrm{~min}$ to allow liquefaction and spermatozoa were then immediately separated from the seminal plasma as described above. The only difference was the use of Dulbecco's phosphate-buffer saline (PBS) with $5 \mathrm{~mm}$-benzamidine $\mathrm{HCl}$ (Fluka AG Buchs, Switzerland), for resuspension of sperm pellets.

Washed spermatozoa were resuspended and kept overnight at $4^{\circ} \mathrm{C}$ in a mixture containing $2 \%(\mathrm{v} / \mathrm{v})$ glacial acetic acid, $10 \%(\mathrm{v} / \mathrm{v})$ glycerol and $50 \mathrm{~mm}$-benzamidine $\mathrm{HCl}$. Extracted spermatozoa were removed from the extract by centrifugation at $10000 \mathrm{~g}$ for $5 \mathrm{~min}$ at $4^{\circ} \mathrm{C}$. Sperm extract was directly chromatographed on Sephadex G-100 column. Details concerning elution characteristics and the assays for proacrosin and acrosin inhibition were as described previously (Čechová et al., 1984). Fractions containing proacrosin were pooled and lyophilized. The proacrosin obtained was free of active acrosin and acrosin inhibitors. The specific activity of proacrosin was $1.5 \mathrm{U} / \mathrm{mg}$ as quantitated by measuring the amount of acrosin activity after maximal autoactivation of proacrosin and expressed in international units (U) using $N \alpha$-benzoyl-D,L-arginine-p-nitroanilide (BAPA) (Serva) as an enzyme substrate. The preparation was kept at $-70^{\circ} \mathrm{C}$ until used.

Source and fractionation of follicular fluid and serum. Human follicular fluid was obtained by puncture and aspiration of preovulatory ovarian follicles in clomiphene/hCG-stimulated cycles. This was done under laparoscopic or ultrasonic guidance in $\mathbf{5 2}$ patients being treated for in-vitro fertilization and embryo transfer. The technique of follicular aspiration and details of ovarian stimulation were as described previously (Tesaŕík et al., 1980). Fluids that were not blood-stained were selected and pooled. Granulosa cells were removed by centrifugation and the fluid was frozen and kept at $-20^{\circ} \mathrm{C}$ until used. Serum samples from all subjects were prepared and stored as above.

Follicular fluids and sera $(4 \mathrm{ml})$ were chromatographed at $25^{\circ} \mathrm{C}$ on a $2.1 \times 100 \mathrm{~cm}$ Sepharose $6 \mathrm{~B}$ column (Pharmacia Fine Chemicals, Uppsala, Sweden) equilibrated with 0.01 M-Tris-HCl buffer containing 0.15 M-sodium chloride ( $\mathrm{pH} 7.5$ ) at $25^{\circ} \mathrm{C}$ (associative conditions) or with the same buffer containing $6 \mathrm{M}$-guanidine hydrochloride (dissociative conditions). Fractions $\sim 3.75 \mathrm{ml}$ were collected at 15 -min intervals. The column was calibrated with Blue Dextran (Serva) and ferritin (Serva).

Protease and acrosin inhibitor activities were measured spectrophotometrically using D,L-BAPA as a substrate as described elsewhere (Železná \& Čechová, 1982).

Detection of proacrosin converting activity in column eluent, determination of its character. Purified proacrosin $(6 \mu \mathrm{g})$ in $0.05 \mathrm{ml} 0.001 \mathrm{M}$-hydrochloric acid was added to the mixture of $2.4 \mathrm{ml} 0.1 \mathrm{M}$-Tris- $\mathrm{HCl}, 0.025 \mathrm{M}$-calcium chloride, $1 \mathrm{mg} \mathrm{D,L-BAPA,} 0.1 \mathrm{ml}$ dimethylformamide, $\mathrm{pH} 7 \cdot 8$, and a $5-\mu l$ sample of the column fraction and incubated at a temperature of $25^{\circ} \mathrm{C}$. The reaction was stopped after $10 \mathrm{~min}$ by adding $0.5 \mathrm{ml} 30 \%$ acetic acid and the absorbance at $405 \mathrm{~nm}$ was measured against that of a control sample containing column buffer instead of eluate. To determine the nature of the proacrosin converting activity, testicular hyaluronidase (Serva) or bovine trypsin (Lečiva, Praha, Czechoslovakia) was added to a concentration of $1 \mathrm{mg} / \mathrm{ml}$ into the samples of eluant from the Sepharose 6B column containing proacrosin converting activity. Everything was kept overnight at $37^{\circ} \mathrm{C}$ and the conversion activity of both samples was determined as mentioned above.

Effect of proacrosin converting activity on the time course for the appearance of activity. The reaction mixture $\left(3^{\circ} \mathrm{C}\right.$,

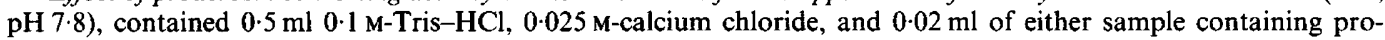
acrosin converting activity in PBS buffer or PBS buffer alone. It was mixed with $80 \mu \mathrm{g}$ proacrosin in $0.5 \mathrm{ml} 0.001 \mathrm{M}$ hydrochloric acid. At the indicated times, $0.05 \mathrm{ml}$ portions were removed and assayed for acrosin activity.

Effect of dilution of material with proacrosin converting activity. Proacrosin $(30 \mu \mathrm{g}) \mathrm{in} 0.05 \mathrm{ml} 0.00 \mathrm{I}$ M-hydrochloric acid was added to a mixture of $0.4 \mathrm{ml} 0.1 \mathrm{M}$-Tris- $\mathrm{HCl}$ and $0.025 \mathrm{M}$-calcium chloride $\left(\mathrm{pH} 7.8,3^{\circ} \mathrm{C}\right)$ and $5 \mu \mathrm{l}$ proacrosin converting activity was diluted as indicated. After $3 \mathrm{~min}$ of incubation, $0 \cdot 1 \mathrm{ml}$ aliquants were removed and assayed for acrosin activity.

Effect of the proacrosin converting activity in the column eluate on human proacrosin. Human proacrosin $(300 \mu \mathrm{l}$ of a Sephadex G-100 column eluate peak fraction, see above) at 0.001 M-hydrochloric acid, was added to $2.7 \mathrm{ml} 0.1 \mathrm{M}$ Tris$\mathrm{HCl}$ buffer, $\mathrm{pH} 7.8$ containing $0.025 \mathrm{M}$-calcium chloride, $1 \mathrm{mg}$ D,L-BAPA and $0.1 \mathrm{ml}$ dimethylformamide. The activity of cleaving D,L-BAPA at $405 \mathrm{~nm}$ was compared in the absence or presence of a sample of $5 \mu \mathrm{l}$ with proacrosin converting activity from the Sepharose $6 \mathrm{~B}$ column fraction.

\section{Results}

\section{Chromatography on Sepharose 6B}

After the separation of follicular fluid by gel filtration on the Sepharose 6B column, material with proacrosin converting activity was eluted in the void volume from the column and was separated from main peaks of acrosin inhibitor activity (Fig. 1). No activity was found in blood serum separated in the same way as follicular fluid. The distribution of acrosin inhibitor peaks in serum was analogous with those in follicular fluid. No differences in elution profile were found using dissociative or associative conditions. 


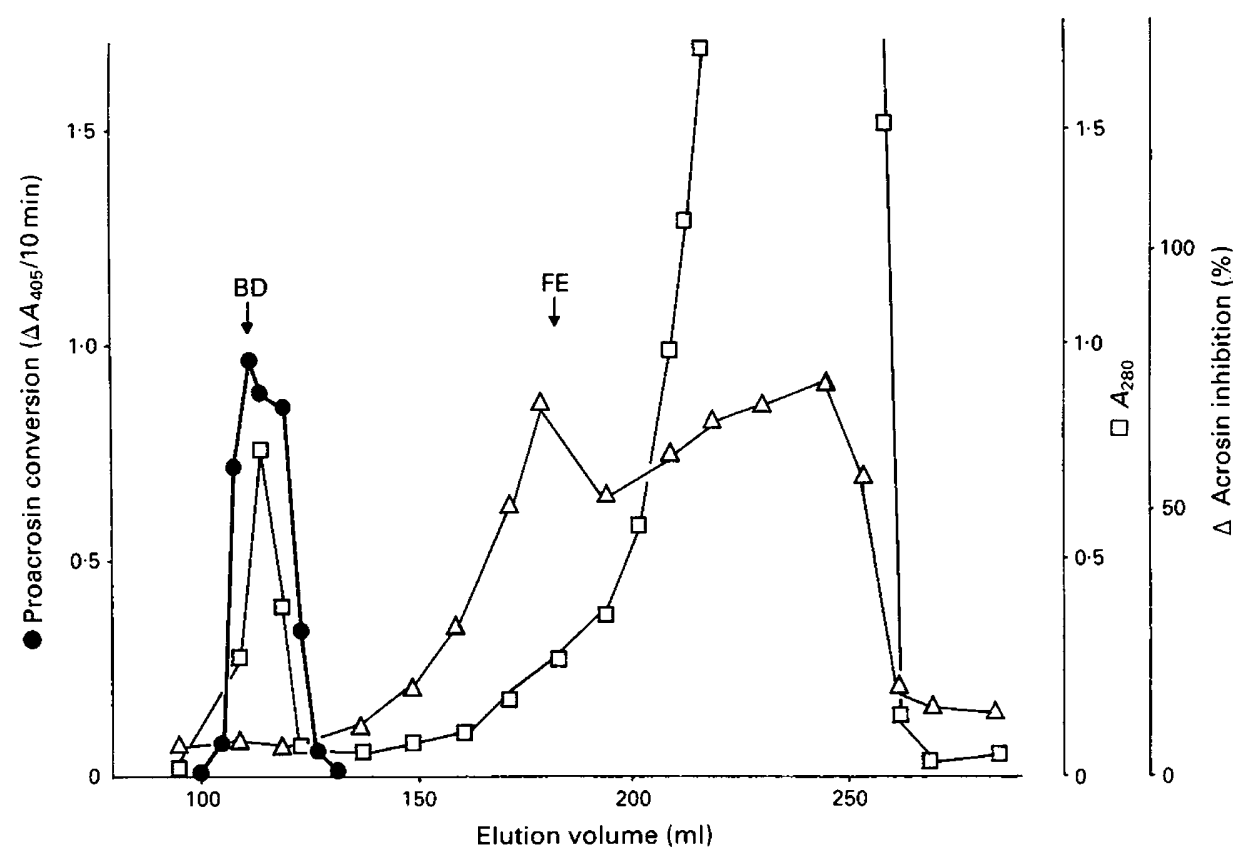

Fig. 1. Sepharose 6B Chromatography of human follicular fluid. Acrosin activity after proacrosin conversion $(\odot)$, acrosin inhibitor activity $(\triangle)$ and absorbance at $280 \mathrm{~nm}(\square)$ are given. Arrows indicate elution volumes of Blue Dextran (BD), and ferritin (FE).

Treatment with trypsin had no effect on the proacrosin converting activity while treatment with testicular hyaluronidase destroyed it outright.

Effect of material with proacrosin converting activity on the conversion of pig and human proacrosin into acrosin

The time-dependent appearance of acrosin peptidase activity at $\mathrm{pH} 7 \cdot 8,3^{\circ} \mathrm{C}$, is shown in Fig. 2 . Proacrosin incubated at $\mathrm{pH} 7.8$ showed a sigmoidal conversion profile in which the time required for one-half maximum activity $\left(t \frac{1}{2}\right)$ was about $150 \mathrm{~min}$. The $t \frac{1}{2}$ was reduced to approximately $2 \mathrm{~min}$ when material with converting activity had been added to the incubation medium. The maximum auto-activation in the absence of the active material was slightly lower than that in its presence. Control experiments indicated that the material did not catalyse the hydrolysis of BAPA and had no effect on the acrosin-catalysed hydrolysis of BAPA. The time-dependent appearance of acrosin peptidase activity as a function of different concentrations of the material with proacrosin converting activity is shown in Fig. 3.

An effect of the proacrosin converting activity on human proacrosin was demonstrated. The addition of a sample of proacrosin converting activity from the column fraction caused an immediate increase of cleavage of BAPA from $0.003 \mathrm{mU}$ to $1.2 \mathrm{mU}$.

\section{Discussion}

The results of this study have shown that human follicular fluid contains a substance(s) that is capable of accelerating the conversion of pig and human proacrosin into acrosin. It follows from the chromatography data that the molecular weight of this activator is at least 3000000 .

The active component is obviously not delivered to follicular fluid by transudation from blood plasma as no activity can be detected in corresponding fractions of human blood serum. Moreover, 


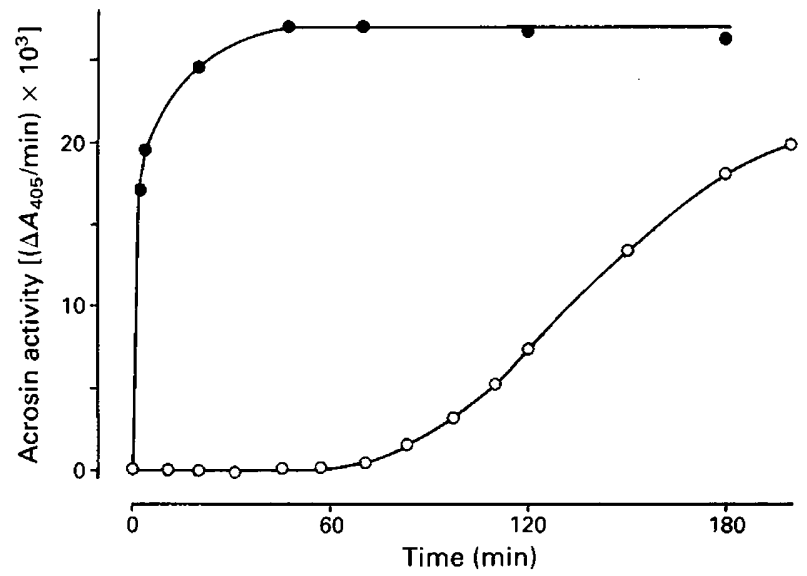

Fig. 2. Effect of material with proacrosin converting activity on the time course for appearance of acrosin activity. Proacrosin conversion in the absence $(O)$ or presence $(O)$ of material with proacrosin converting activity.

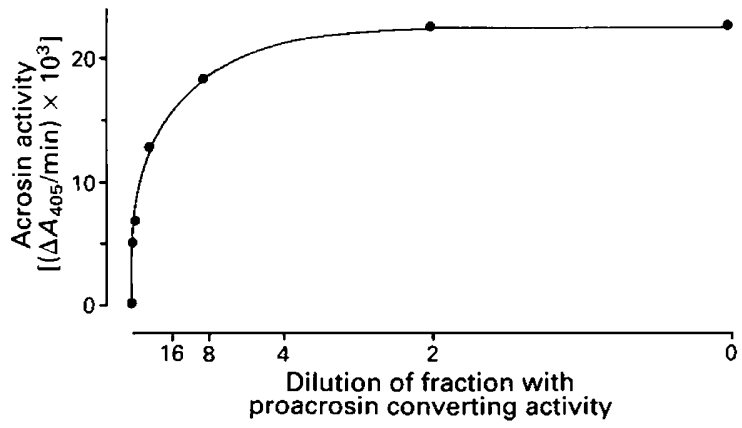

Fig. 3. Dependence of stimulation of proacrosin conversion on the concentration with proacrosin converting activity.

the follicular wall is known to act as a molecular sieve and transfer of molecules with such a high molecular weight as that of the proacrosin activator described here would be most unlikely to occur at any reasonable rate. Hence, the substances showing proacrosin converting activity must be produced locally, within follicles, and granulosa and/or cumulus cells appear to be the most likely source.

Proacrosin converting activity in the follicular fluid can be expected to have a direct effect on sperm fertilizing ability because the contact of the fertilizing spermatozoon with follicular fluid components takes place at a moment relatively close to fertilization. If cumulus cells do produce the active substance (which remains to be proved), the cumulus matrix may contain high levels of the activity and the active molecules may also impregnate the outer parts of the zona pellucida, as occurs with the proteoglycans secreted by preovulatory human cumulus cells (Tesařík \& Kopečný, 1986). If we assume further that the action of acrosin is necessary for sperm penetration through the zona pellucida (see review by Talbot, 1985) and that the fertilizing spermatozoon undergoes the acrosome reaction, which is a prerequisite for in-situ proacrosin activation, in the cumulus oophorus or at the zona surface (for reviews see Bedford, 1983; Phillips, 1984; Meizel, 1985), the acceleration of the zymogen conversion at this time seems to coincide with the period when the physiological role of acrosin is realized. However, proacrosin converting activity is not consistent 
with the acrosome reaction activator that has been discovered in human follicular fluid and whose apparent molecular weight is about 45000 (Suarez et al., 1986).

The fact that the proacrosin conversion activity is destroyed by treatment with testicular hyaluronidase and not by treatment with trypsin indicates that the component responsible for proacrosin conversion is a chondroitin-like glycosaminoglycan. In view of its high molecular weight, the purified active molecules might be proteoglycans.

The isolation and chemical characterization of the molecules responsible for the proacrosin converting activity in human follicular fluid are in progress.

We thank Dr J. Pácová, from the Center of Pig Insemination Development, Rajhrad, C.S.S.R. for generously donating the boar semen.

\section{References}

Bedford, J.M. (1983) Significance of the need for sperm capacitation before fertilization in eutherian mammals. Biol. Reprod. 28, 108-120.

Brown, C.R. \& Harrison, R.A.P. (1978) The activation of proacrosin in spermatozoa from ram, bull and boar. Biochim. Biophys. Acta 526, 202-217.

Čechová, D., Železná, B., Petelíková, J. \& Pavlok, A. (1984) Boar proacrosin. Correlation between total proacrosin content and sperm fertilizing capacity. Andrologia 16, 169-174.

Green, D.P.L. (1978) The activation of proteolysis in the acrosome reaction of guinea-pig sperm. J. Cell Sci. 32, 153-164.

Handrow, R.R., Lenz, R.W. \& Ax, R.L. (1982) Structural comparisons among glycosaminoglycans to promote an acrosome reaction in bovine spermatozoa. Biochem. Biophys. Res. Commun. 107, 1326-1332.

Harrison, R.A.P. \& Brown, C.R. (1979) The zymogen form of acrosin in testicular, epididymal, and ejaculated spermatozoa from ram. Gamete Res. 2, 75-87.

Lenz, R.W., Ball, G.D., Lohse, J.K., First, N.L. \& Ax, R.L. (1983a) Chondroitin sulfate facilitates an acrosome reaction in bovine spermatozoa as evidenced by light microscopy and in vitro fertilization. Biol. Reprod. 28, 683-690.

Lenz, R.W., Bellin, M.E. \& Ax, R.L. (1983b) Rabbit spermatozoa undergo an acrosome reaction in the presence of glycosaminoglycans. Gamete Res. 8, 11-19.

Meizel, S. (1985) Molecules that initiate or help stimulate the acrosome reaction by their interaction with the mammalian sperm surface. Am. J. Anat. 174, 285-302.

Meizel, S. \& Turner, K.O. (1986) Glycosaminoglycans stimulate the acrosome reaction of previously capacitated hamster sperm. J. exp. Zool. 237, 137-139.

Mukherjee, A.B. \& Lippes, J. (1972) Effect of human follicular and tubal fluids on human, mouse and rat spermatozoa in vitro. Can. J. Genet. Cytol. 14, 167-174.

Oliphant, G., Cabot, C. \& Singhas, C. (1977) Nature of the rabbit acrosome reaction-inducing activity of follicular fluid. J. Reprod. Fert. 50, 245-250.

Parrish, R.F., Wincek, T.J. \& Polakoski, K.L. (1980) Glycosaminoglycan stimulation of the in vitro conversion of boar proacrosin into acrosin. J. Androl. 1, $89-95$.
Phillips, D.M. (1984) Problems in the analysis of mammalian fertilization. In Ultrastructure of Reproduction, pp. 166-175. Eds J. Van Blerkom \& P. M. Motta. Martinus Nijhoff, Boston.

Polakoski, K.L. \& Parrish, R.F. (1977) Boar proacrosin. Purification and perliminary activation studies of proacrosin isolated from ejaculated boar sperm. $J$. biol. Chem.252, 1888-1894.

Reyes, R., Carranco, A., Hernandez, O., Rosado, A., Merchant, H. \& Delgado, N.M. (1984) Glycosaminoglycan sulfate as acrosome reaction-inducing factor of follicular fluid. Archs Androl. 12, 203-209.

Stambaugh, R. \& Mastroianni, L., Jr (1980) Stimulation of rhesus monkey (Macaca mullata) proacrosin activation by oviduct fluid. J. Reprod. Fert. 59, 479-484.

Suarez, S.S., Wolf, D.P. \& Meizel, S. (1986) Induction of the acrosome reaction in human spermatozoa by a fraction of human follicular fluid. Gamete Res. 14, $107-121$.

Talbot, P. (1985) Sperm penetration through oocyte investments in mammals. Am. J. Anat. 174, 331-346.

Tesařik, J. (1985) Comparison of acrosome reactioninducing activities of human cumulus oophorus, follicular fluid and ionophore A23187 in human sperm populations of proven fertilizing ability in vitro. $J$. Reprod. Fert. 74, 383-388.

Tesaří, J.\& Kopečný, V. (1986) Late preovulatory synthesis of proteoglycans by the human oocyte and cumulus cells and their secretion into the oocyte-cumuluscomplex extracellular matrices. Histochemistry 85, 523-552.

Tesařík, J., Dvořák, M., Pilka, L., Uher, M. \& Soška, J. (1980) Die Wirkung der laparoskopischen Aspiration des Graafschen Follikels auf die Ultrastruktur von Oozyten. Zentbl. Gynaekol. 102, 641-644.

Tobias, P.A. \& Schumacher, G.F.B. (1977) Observation of two proacrosins in extracts of human spermatozoa. Biochem. Biophys. Res. Commun. 74, 434-439.

Wincek, T.J., Parrish, R.F. \& Polakoski, K.L. (1979) Fertilization: a uterine glycosaminoglycan stimulates the conversion of sperm proacrosin to acrosin. Science, N.Y. 203, 553-554.

Železná, B. \& Cechová, D. (1982) Boar acrosin. Isolation of two active forms from boar ejaculated sperm. Hoppe-Seyler's Z. Physiol. Chem. 363, 757-766.

Received 7 September 1987 